Working Paper 8501

A BUREAUCRATIC THEORY OF FLYPAPER EFFECTS

by Paul Gary Wyckoff

Working papers of the Federal Reserve Bank of Cleveland are preliminary materials circulated to stimulate discussion and critical comment. The views expressed are those of the author and not necessarily those of the Federal Reserve Bank of Cleveland or the Board of Governors of the Federal Reserve System.

The author would like to thank Professor Harvey Brazer of the University of Michigan for his guidance on the author's Ph.D. dissertation, from which this paper was developed.

June 1985

Federal Reserve Bank of Cleveland 


\section{A BUREAUCRATIC THEORY OF FLYPAPER EFFECTS}

\section{Abstract}

One well-documented pattern in local public finance is that, in comparison with what is spent out of residents' private income, a disproportionate amount of the lump-sum aid received from higher levels of government is used to increase expenditures rather than reduce local taxes. This paper shows how a bureaucratic model of the type suggested by Niskanen (1971) can be used to explain this behavior. A test of the model, using 115 small city governments in Michigan, finds that the bureaucratic model explains capital expenditures well, while operating expenditures appear to be better explained by the standard median voter model.

\section{I- Introduction}

Early writers in the theory of public choice recognized a connection between the outcome of electoral processes and the demands of a particular constituent--the median voter (see Hotelling [1929], Black [19481, and Bowen [1943]). Consistent with this hypothesis, later empirical analysts (see Borcherding and Deacon [1972], Bergstrom and Goodman [1973], and Inman [1978]) showed that statistically significant relationships exist between local government expenditures and the median voter's income and tax price. The median voter model, however, faces serious theoretical and empirical challenges. One difficulty is the troubling possibility that the output of the community (and 
the price it pays for public goods) might be distorted by inefficiencies created by the government agencies that actually produce public goods. This possibility is particularly important because the median voter model's chief rival in the public choice literature is a set of "bureaucratic" theories of government behavior. In these models, public bureaus are seen as exercising monopoly control over publicly produced goods and services. They use this monopoly power to coerce elected officials into approving larger budgets at higher cost per unit than would otherwise occur, to enhance the personal prestige, income, and power of the bureaucrat.

A second problem with the use of the median voter model involves a consequence of the model that is consistently refuted by empirical tests. Bradford and Oates (1971) have shown that, under a system of majority rule voting, the effects of any system of revenue sharing can be duplicated by a set of grants to individuals in the community of the same amount, because the crucial median voter faces the same budget constraint in either case.

Empirically, this theorem implies that increases in noncategorical grants to the community, when appropriately weighted by the median voter's tax share, ought to stimulate the same amount of spending as increases in his income. In separate surveys of the effect of aid on spending, Gramlich (1977) and Fisher (1982) note that this equivalence is consistently rejected by the data--a lump-sum aid increase of $\$ 1$ generates more expenditure than an income increase of T dollars. This phenomenon has been dubbed the "flypaper effect", since revenue sharing money sticks in the public sector where it first enters the community, instead of being distributed to the private sector in the form of lower taxes.

This paper shows how these bureaucratic theories can be used to modify the median voter model to explain flypaper effects. The intuition behind the 
results is quite straightforward: having additional private income alters the median voter's bargaining position with respect to local bureaus in a way that additional lump-sum aid does not. Section II explains the nature of flypaper effects. Section III details the particulars of the model, beginning with the assumptions on which it is based. Section IV presents an empirical test, using expenditure data from 115 small city governments in Michigan. The article concludes with some brief comments about extensions of the model.

\section{Flypaper Effects}

Figure 1, adapted from Bradford and Oates (1971), illustrates the precise meaning of the flypaper effect. An unrestricted grant of amount A pushes out the median voter's budget constraint as shown, but leaves its slope unaffected. Since this slope is equal to the median voter's tax share (labeled T), an income increase of amount TA results in exactly the same final budget constraint as that under the aid increase. As long as the voter's preferences are independent of the elements of this budget constraint, the same equilibrium expenditure on public and private goods should occur. In this sense, the aid increase of $A$ is equivalent, under the median voter model, to an income increase of the amount TA.

Another way of looking at this result is that the median voter, as a participant in the local decision-making process, can claim some portion of the community's shared resources (including lump-sum aid from higher levels of government) as his own. If the aid is used to reduce local taxes, he will recieve $\mathrm{T}$ times the lump-sum aid in higher after-tax income. Being the dominant actor in local politics, the median voter can move these resources in and out of the public sector at will, converting his share of lump-sum aid to public 
Fig. 1 Median Voter Model: Equivalence of an Unrestricted Grant of Amount A to an Income Increase of Amount TA

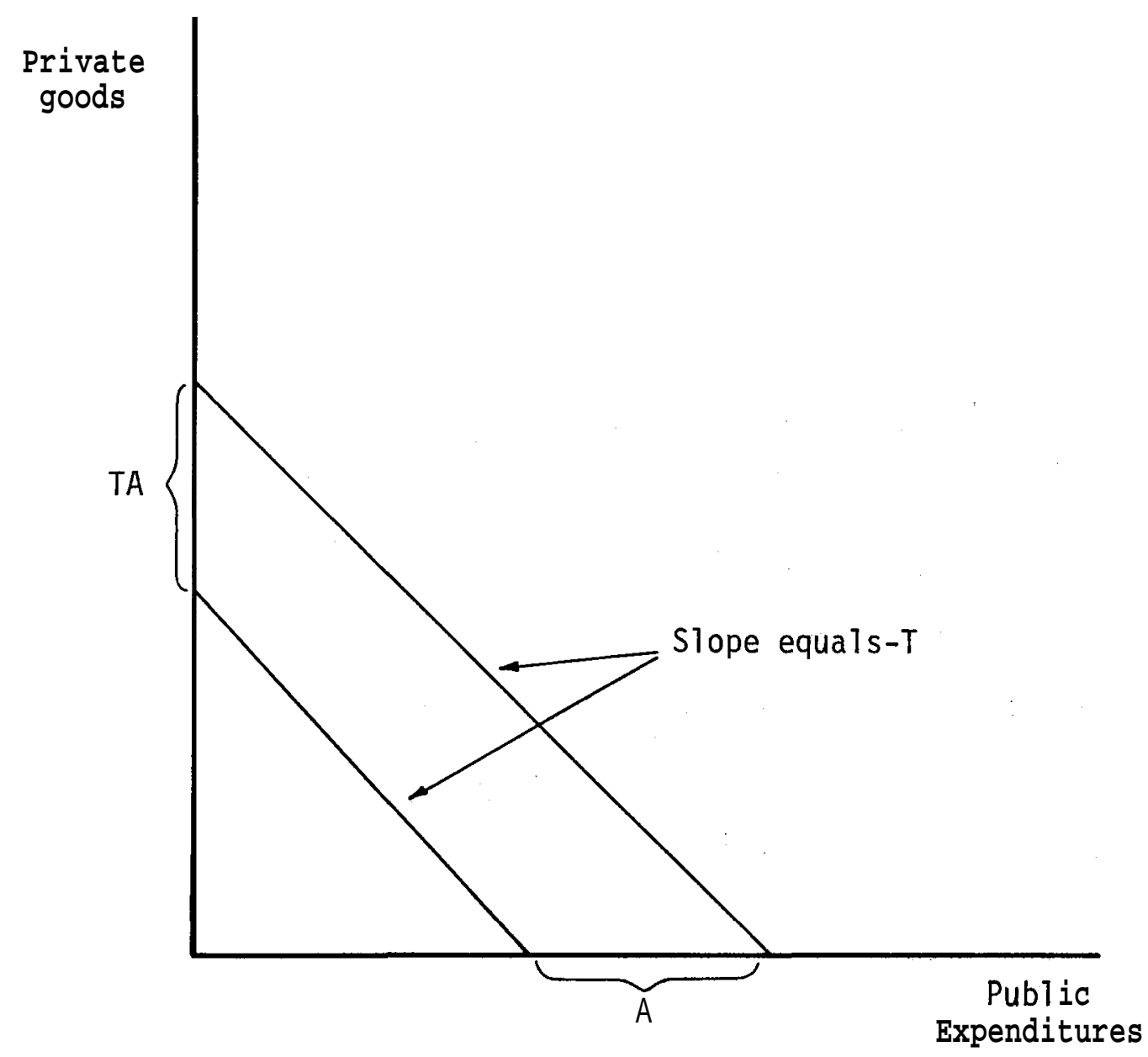


expenditure at an exchange rate equal to his tax share. Since the funds are perfectly fungible, the value of his "public income" (TA) can simply be added to his private income $(Y)$ to get his effective income $(Z)$ :

(1) $\quad Z=Y+T A$.

It follows that under the median voter model:

$$
\partial E / \partial A=[\partial E / \partial(T A) 1[\partial(T A) / \partial A]=[\partial E / \partial(T A) \mid T=T(\partial E / \partial Y),
$$

where

$$
E=\text { local government expenditure. }
$$

In elasticity terms, this can be rewritten as:

$$
\varepsilon_{E, A}=(A T / E)(\partial E / \partial Y)=(A T / E)(E / Y)(Y / E)(\partial E / \partial Y)=(A T / Y) \varepsilon_{E, Y} .
$$

However, as Fisher (1982) demonstrates, these theoretical equivalences are, on the whole, not supported by the data. Of the eleven studies surveyed by Fisher, only one failed to find evidence of flypaper effects. In the case of studies reporting marginal effects, the expenditure effect of lump-sum aid ranged from $\$ 0.20$ to $\$ 1.60$ larger than predicted by the theory. For those studies reporting elasticities, the expenditure effects were from zero to 71 percent larger than expected. Moreover, flypaper effects results occurred across a wide variety of data sets and empirical methodologies. A survey by Gramlich (1977) reached similar conclusions about the existence of flypaper effects: "Whether half or all the revenue sharing money goes into higher expenditures, however, at this point all empirical studies indicate long-run responses appreciably greater than would be implied by the response of expenditures to changes in income ..." (see Gramlich [1977], p. 230). 


\section{A Bureaucratic Model of Local Public Choice}

\section{A. Assumptions}

The model is based upon four principal assumptions.'

(A.1) Actors in the Model. The local budget process for each public good is fundamentally a two-way struggle between the city council and the local department (or bureau) that produces the good. ${ }^{2}$

(A.2) Preferences of the Actors. The preferences of the city council as a whole are the same as those of the median voter in each community. Each department head is interested in maximizing the budget of his bureau.

This specification of the maximand of the local department head (or bureaucrat) follows Niskanen (1971). Niskanen's view is that bureaucrats value salary, the perquisites of office, and patronage, as well as more abstract goals such as public reputation and power over others, and that all these factors are systematically related to the size of the department's budget.

(A.3) Information in the Model. The bureaucrat possesses an information advantage over the town council in assessing the true minimum cost of producing public goods.

Council members and department heads are not likely to find themselves on an equal footing with regard to the information needed to make budgeting decisions. By virtue of his professional training and day-to-day contact with the department, the bureaucrat has a distinct advantage over his sponsors in knowing both the production function for public goods (what inputs are needed for a particular level of output) and the minimum cost at which inputs may be obtained. There is an incentive for the bureaucrat to conceal and distort this 
information, so that the council has no independent basis for judging budget requests.

(A.4) Relations Among the Bureaus. The department heads in each city behave as if production of all public goods took place under one multi-product "superbureau". 3

B. A Utility-Based Niskanen Model

It is assumed at the outset that goods can be meaningfully aggregated into two groups. Good 1 is a composite private good, and its price is normalized to equal one. Good 2 is a composite of the public goods produced by the local bureaus, and its price to the community is $P_{2}$.

The bureaucrat's information advantage over city council gives him power over the city's expenditure decisions. In the extreme case, which is modeled here, the city council has no information whatever about the cost of public goods, and therefore has no information about the effects of marginal changes in budgets proposed by the bureau. A risk-averse city council will therefore tend to avoid making changes in the bureau's budget. This uncertainty about marginal changes is compounded by strategic behavior on the part of the bureau; the bureaucrat reacts to cuts in the budget by eliminating the most popular programs first. Since risk-aversion and strategic bureau behavior make marginal changes unpalatable, the city council is reduced to a binary choice between two choices about which it is certain: either accept the bureau's budget in its entirety, or do without the bureau altogether.

This weakness on the part of city council allows the bureaucrat in this model to maximize his budget subject to two constraints: revenues must cover costs, and the median voter must not be put in a position where he could improve his lot by eliminating the bureau entirely. Whatever the next best 
alternative to bureau production might be, it is associated with a particular utility level for the median voter, which I will label $U_{0}^{v}$. In order to ensure its survival, then, the aggregate bureau must not push the median voter's utility level below $U_{0}^{v}$.

Algebraically, it is easy to show that, under this model, the fol lowing equality is always satisfied:

(4)

$$
A+\left(Y-f\left[X_{2}, U_{0}^{\vee}\right]\right) / T=c\left(X_{2}\right)
$$

where:

$A=$ lump sum grants to the city, $c\left(X_{2}\right)=$ the true cost function for $X_{2}$, $\mathrm{T}=$ median voter's tax share,

$X_{1}=f\left(X_{2}, U_{0}^{v}\right)$, the equation for the median voter's indifference curve at utility level $\mathrm{U}_{0}^{v}$, and $Y=$ median voter's private income.

To demonstrate this point, note that the following three conditions must be satisfied:
a) $Y+T A=X_{1}+T P_{2} X_{2}$ (median voter budget constraint),
b) $P_{2} X_{2}=c\left(X_{2}\right)$ (cost constraint), and
c) $U_{0}^{v}=U\left(X_{1}, X_{2}\right)$ (utility constraint). ${ }^{4}$

Since utility is monotonic in $X_{1}$, condition $c$ can be inverted to get $X_{1}=f\left(X_{2}, U_{0}^{v}\right)$. We can substitute for $X_{1}$ in condition $a$, and when this is rearranged, the formula for $P_{2}$ emerges:

$$
P_{2}=A B=\left(Y+T A-f\left[X_{2}, U_{0}^{v}\right]\right) / T X_{2} .
$$


This tells us the maximum price that the bureau can charge at each $X_{2}$. Substituting this into the cost constraint (b) yields equation (4).

The top panel of figure 2 illustrates the geometry of equation (4), while also demonstrating an additional necessary condition for maximization in the model. Not only must the total revenue and total cost curves intersect, but the total revenue function must cut through the total cost function from below. Under normal circumstances, the total revenue function, $\mathbb{R}=A+\left(Y-f\left[X_{2}, U_{0}^{\vee}\right]\right) / T$, is a hyperbola thạt is asymptotic to the dollar axis and the line $\mathbb{R}=Y / T+A$. For the case of constant marginal cost, it cuts the total cost line in two places, but only the second intersection maximizes the budget. Formally, $-f_{1} / T$ (the slope of the $\mathbb{R}$ line, where $f$, represents the derivative of $f$ with respect to its first argument) must be less than $c^{\prime}\left(X_{2}\right)$ (the slope of the TC line). Otherwise, the bureau should be able to expand further, since additional output will cover its costs.

The bottom half of figure 2 compares the outcome of this bureaucratic model to the median voter model for the case of constant marginal costs. Equation (5) describes the locus of all points in the $\left(P_{2}, X_{2}\right)$ space that give the median voter utility level $U_{0}^{v}$. Although Niskanen calls this locus the "marginal value function," and Patinkin (in another context) calls it the "all-or-none" demand curve (Patinkin 1963, pp. 83-8), I will use the term average benefit ( $A B$ ) curve. As my terminology implies (and despite Niskanen's imprecise use of the term marginal in this context), this $A B$ curve is related to the Hicksian demand (or marginal benefit) function as average is related to marginal. Total revenue $\left(P_{2} X_{2}\right)$ at any point on this $A B$ curve will always be equal to the area under the corresponding Hicksian demand curve. 
Fig. 2 Budget-Maximizing and Median Voter Mode1s Compared

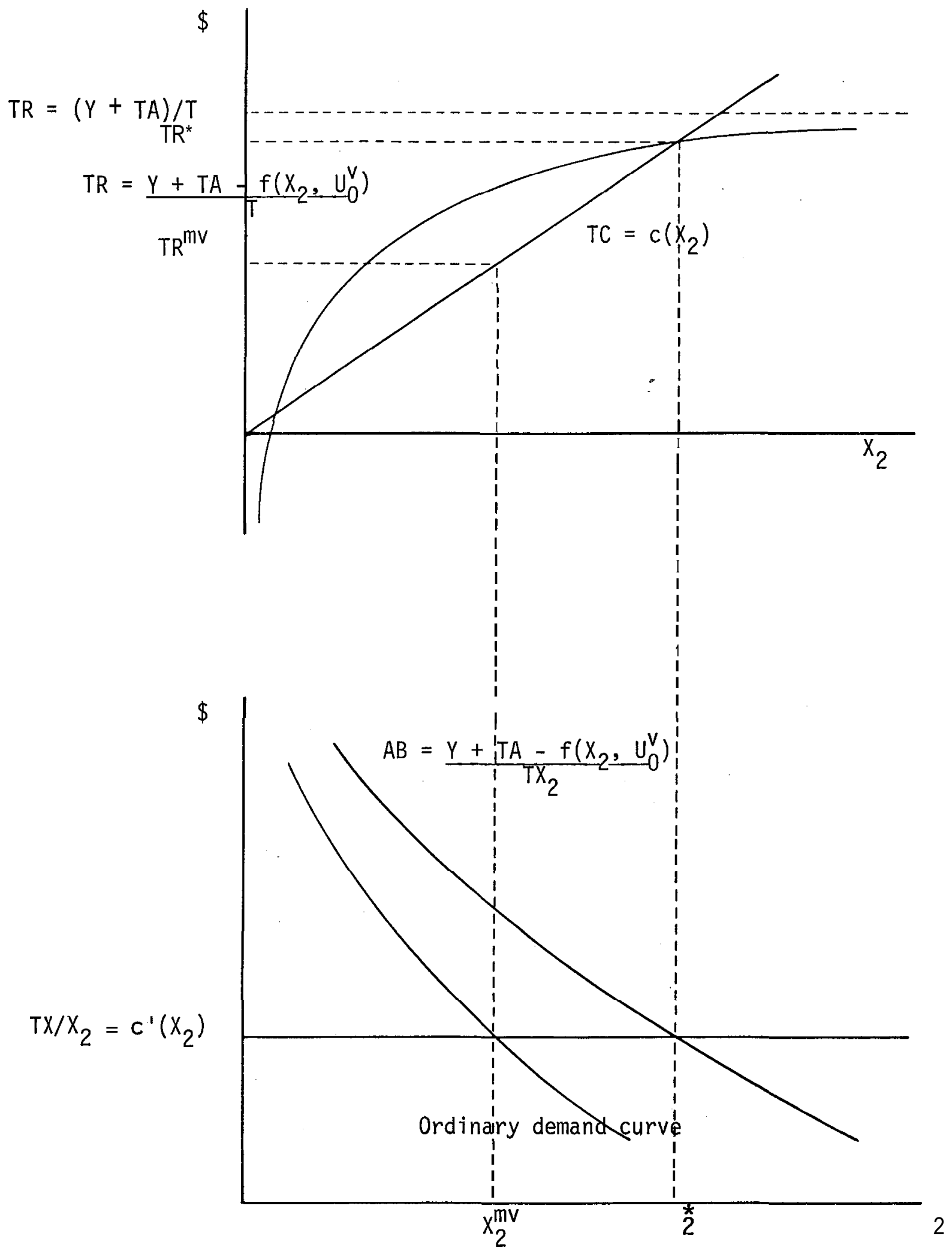


The $A B$ curve should not be confused with more common kinds of demand curves in economics, such as the Hicksian and Marshallian (or ordinary) demand curves. In the spirit of binary choice just described, the $A B$ curve does not assume that the consumer adjusts his purchases to maximize his welfare. Rather, for every given $P_{2}$, the curve relates how much total output the bureau can force the consumer to accept and pay for before the consumer decides to abandon the bureau entirely. The curve slopes downward because the consumer-voter will allow a little more allocative inefficiency (i.e., he is forced to buy more goods than he would like at the prevailing price) in exchange for a little less productive inefficiency (i.e., a price closer to true cost).

As figure 2 shows, output under the budget-maximizing model is allocatively, but not productively, inefficient from the viewpoint of the median voter. The median voter model dictates output $X_{2}^{m v}$ at the intersection of the marginal cost and ordinary demand curves; the bureaucratic model predicts output $X_{2}^{*}$ at the intersection of the average cost and $A B$ curves. Output is produced at cost $\left(\operatorname{soc} c\left(X_{2}\right)=E\right.$, where $E=$ expenditures $)$, but relative to the median voter case too many units of public goods are produced, and the bureau's budget is too large.

The Niskanen model has two well-known comparative static results: first, output is always cost-elastic; and second, a $\$ 1$ increase in lump-sum aid will generate more than a $\$ 1$ increase in expenditures (for proofs in the context of the current formulation of the model, see Wyckoff [1984]). Here I concentrate on a new implication of the model in the local government case: its generation of flypaper effects. Loosely put, these occur because the extra private income is "transportable" to the median voter's next best alternative in a way that aid is not. Or to put it another way, the private 
income is fungible, so that it can be used in alternative situations, while the aid is not.

In the most common situation, the voter's next best alternative is to move to a new city. If he moves, the voter can utilize his extra private income in this new situation, but he cannot take his share of aid to the new location -- it is tied to his current city of residence. ${ }^{5}$ Since aid is not available in the median voter's next best alternative situation, increases in aid fail to increase $U_{0}^{v}$, but increases in private income undoubtedly do change that value. ${ }^{6}$ The increase in $U_{0}^{v}$ helps to restrain the growth of spending by the bureaucrat in the case of higher private income but not in the case of increases in aid. This is the source of flypaper effects.

In more intuitive terms, private income increases improve the voter's bargaining position in budget discussions, but increases in aid do not. As an analogy, note that the outcome of negotiations between management and labor often depend upon the suffering each side will endure if no agreement is reached. If management can demonstrate that it is not unduly harmed by the shutdown of its facilities (that is, its $U_{0}^{2}$ is high) it can often take a tougher negotiating stance and force concessions from the workers.

The reader may also see parallels here with the papers by Romer and Rosenthal (1980) and Filimon, Romer, and Rosenthal (1982), where it was shown that, if the state imposes a "reversion level" on the decisions of a budget-maximizing school board--a level of taxes and expenditures that would prevail if voters failed to approve the district's tax levy--spending outcomes can be affected by any change that occurs in that reversion level. Here, $\mathrm{U}_{0}^{v}$ amounts to a "natural" reversion level, not imposed by the state, but by the circumstances faced by the median voter. An increase in income increases the utility of this reversion level and forces the bureau to 
restrain its budget demands, while the aid increase does not.'

To prove this proposition, note that, as long as the cost function $C=c\left(X_{2}\right)$ is monotonic, there exists an inverse function $X_{2}=g(C)$, which maps cost into a unique level of output. Then the Niskanen model can be characterized by:

(6)

$$
C=A+\left(Y-f\left[g(C), U_{0}^{v}\right]\right) / T
$$

Therefore:

(7) $\quad \partial C / \partial A=1-\left(f_{1} g^{\prime} / T\right) \partial C / \partial A$.

But, since $g$ is an inverse function, $g^{\prime}=1 / c^{\prime}$. Substitution and rearrangement result in:

$$
\partial C / \partial A=1 /\left(1+f_{1} / T C^{\prime}\right) \text {. }
$$

This means that:

$$
\frac{\partial C}{\partial T A}=\frac{\partial C}{\partial A} \frac{\partial A}{\partial T A}=\frac{1}{T+f_{1} / C^{\prime}}
$$

With respect to y, differentiation of equation (4) can be performed in exactly the same fashion as was used to establish $\partial \mathrm{C} / \partial A$. This time, however, the dependence of $U_{0}^{v}$ on $Y$ must be considered. When the results are rearranged, this yields:

(10)

$$
\frac{\partial C}{\partial Y}=\frac{1-f_{2} \partial U_{0}^{v} / \partial Y}{T+f_{1} / C^{\prime}}
$$

where

$$
f_{2}=\partial f\left(X_{2}, U_{0}^{v}\right) / \partial U_{0}^{v} .
$$

Since $f_{2}$ and $\partial U_{0}^{v} / \partial Y$ are both positive, $-f_{2} \partial U_{0}^{v} / \partial Y$ reduces the size of the numerator in this last equation. The result from figure 2 that $-f_{1} / T<c^{\prime}\left(X_{2}\right)$ ensures that the denominator is positive. Hence, a comparison of (9) and (10) shows that:

$$
\partial E / \partial T A=\partial C / \partial T A<\partial C / \partial Y=\partial E / \partial Y .
$$




\section{An Empirical Test of the Model}

\section{A. Additional Assumptions}

To test the model just described, four additional assumptions are made. All of these assumptions are more or less standard in the literature on testing the median voter model (see, for example, Borcherding and Deacon [1972] and Bergstrom and Goodman [1973]).

(A.5) The cost function for production of public facilities exhibits constant marginal and average costs. The cost of another unit of facilities may vary across jurisdictions, but it does not vary with the level of output in any particular jurisdiction.

(A.6) Units of public facilities and units of public services are related by the following "sharing function":

$$
X_{2}=X_{2}^{f} / n^{a}, 0 \leq a \leq 1
$$

where

$$
\begin{aligned}
& \mathrm{X}_{2}=\text { the quantity of local public services provided, } \\
& \mathrm{X}_{2}^{\mathrm{f}}=\text { the quantity of local public facilities provided, } \\
& \mathrm{n}=\text { the population of the city, and } \\
& \mathrm{a}=\text { a crowding parameter (to be determined by the data), } \\
& \quad \text { which equals zero when local pubiic goods are pure } \\
& \quad \text { public goods and } 1 \text { when they are pure private goods. }
\end{aligned}
$$

This specification allows local public goods to be "impure."

(A.7) The median voter is part of the household with median family income for the community. ${ }^{\text {s }}$ 
(A.8) The median voter owns the house with median value for the city, and this constitutes his entire holding of taxable property. Also, the median voter bears no part of the taxes paid by business firms in the community. ${ }^{9}$

To justify assumptions (A.7) and (A.8), a log-linear functional form is employed, and the results derived by Bergstrom and Goodman (1973) are utilized. These results are designed to deal with the problem that the median voter-median income correspondence may be broken by factors that cause the demand for local public goods to be a non-monotonic function of income. Bergstrom and Goodman show that, as long as the distribution of incomes within each subgroup having distinct demands (i.e., homeowners and renters) is proportional across cities, median quantity demanded will be a log-linear function of median income in each city and the proportion of citizens belonging to each group (see Bergstrom and Goodman [1973] pp. 295-6). The Bergstrom and Goodman methodology is followed in this paper by including percentage owner-occupied, percentage nonwhite, and percentage aged 65 and over among the independent variables in the estimating equation.

\section{B. Estimated Equation and Test Procedures}

The following functional form was used in testing the model:

$$
\begin{aligned}
\ln E_{1}= & b_{0}+b_{1} \text { In POP, }+b_{2} \text { in } T_{1}+b_{3} \text { in } Z, \\
& b_{4} \text { in INCRATIO, + } b_{5} \text { In OTHERAID }+b_{6} \text { DENSITY, } \\
& +b_{7} \text { PEROWN }_{1}+b_{8} \text { PENONW } 1+b_{9} \text { PER65AO }_{1}+\varepsilon_{1},
\end{aligned}
$$

where

$$
\begin{aligned}
& E_{1}= \text { expenditures on all functions except utilities (water, } \\
& \text { electricity, gas, and transit systems) and health (including } \\
& \text { hospitals) for the fiscal year ending between July 1, 1976, } \\
& \text { and June } 30,1977 ;
\end{aligned}
$$


POP $_{1}=1970$ city population;

$T_{1}=\operatorname{tax}$ share of the median voter. $T_{1}$ equals median house value, 1970, divided by 2 times state equalized valuation for the community, 1970 (in Michigan, state equalized valuation is set at one-half of the true cash value of property);

$Z_{1}=$ total income of the median voter, both public and private; $\mathbf{Z}_{1}=$ median family income, $1970+\mathrm{T}_{1}$ * REVSHARE $_{1}$. REVSHARE $_{1}=$ the total amount of state and federal revenue sharing received by the community. REVSHARE, includes all aid given for general local government support (for example, distributions from the state sales tax), but not money granted for specific categories of expenditure (for example, money from state gasoline taxes that are earmarked for street and highway expenditures).

INCRATIO $_{1}=$ the proportion of $Z$ provided by revenue sharing. INCRATIO, $=T_{1}{ }^{*} \operatorname{REVSHARE}{ }_{1} / Z_{1}$;

OTHERAID $_{1}=$ non-revenue sharing aid received by the community;

DENSITY, = density of the city, given by POP, divided by land area in square miles;

PEROWN $_{1}=$ percentage of occupied residences in the city that are owner-occupied, 1970;

PERNONW $_{1}=$ percentage of population that is nonwhite, 1970;

PER65AO 1 = percentage of population age 65 and over, 1970, and

$\varepsilon_{1}$ is an independently and identically distributed disturbance term with zero mean and finite variance. The error term reflects four random elements in the model:

1) errors on the part of the bureaucrat in perception of the demands of the median voter because his knowledge of these demands is imperfect,

2) differences in tastes and preferences among median voters because the voter's demands are not uniquely determined by his income, tax share, and the features of his community,

3) errors due to the uneven distribution of capital outlays, since capital spending, rather than the true value of depreciation, is included in expenditures, and

4) differences in the true cost of producing public goods across communities, which may affect both the demand of the median voter and.the price charged for city services. 
The existence of bureaucratic power in city expenditure decisions was tested using a two-part methodology involving the parameters $b_{1}$ and $b_{4}$. The importance of $\mathbf{b}_{1}$ hinges on the unusual role of the variable POP in the empirical specification just described. Population has no place in the model per se; its only role is in affecting the cost of producing public services. Let $c_{0}$ be the cost of producing a unit of public facilities, while $c_{1}$ is the cost of producing a unit of public services. Using assumptions (A.5) and (A.6), we have that:

(12) $\quad c_{11}=\frac{\partial c_{1}\left(X_{2}\right)}{\partial X_{2}}=\frac{\partial c_{1}\left(X_{2}\right)}{\partial X_{1}^{:}} \frac{\partial X_{2}^{f}}{\partial X_{1}}=c_{0}, n^{a}$

Let $\delta$ be the city's cost elasticity of expenditure on public goods. Then, the price component of the estimating equation would theoretically be:

(13) $6 \ln c_{11}=6 \ln c_{0} n^{a}=6 \ln c_{01}+\delta a \ln n$.

If the unobservable $c_{0}$, are randomly distributed and independent of the other variables on the right-hand side, we can follow Bergstrom and Goodman in characterizing 6 ln $c_{0}$, as simply an additional component of the error term $\varepsilon_{1}$. The term $6 a \mathrm{ln} n$, on the other hand, corresponds to the term $b_{1}$ In POP, in (11); therefore, $b_{1}=6 a$.

Under the null hypothesis (the median voter model), 6 has no restriction; the cost elasticity of expenditure can be anything at all. Hence there are also no restrictions on $\mathbf{b}_{1}$. On the other hand, the Niskanen model is characterized by cost elastic demand, which results in an inverse relationship between cost per unit and expenditure. Therefore, under these 
alternatives, $6<0$. Since $0 \leq a \leq 1$ by assumption, this model requires that $b_{1}=6 a \leq 0$.

Variable $Z$ above is simply the total income of the median voter under the Bradford-Oates theorem that one dollar of lump sum aid is equivalent to $T$ dollar's worth of income. The variable INCRATIO puts this theorem to the test; if the median voter paradigm holds, the composition of this income between grants and private income shouldn't matter, and $b_{4}=0$. Under the Niskanen theory, expenditure should rise with the proportion of $Z$ that comes from revenue sharing, so $\mathbf{b}_{4}$ is greater than zero.

Our sample consists of 115 cities in Michigan with 1970 populations between 2,500 and 57,000, located outside the southeast corner of the state (Wayne, Oakland, and Macomb counties). ${ }^{\circ}$ The data for these communities came from the 1970 Censuses of Population and Housing, the 1977 Census of Governments, and from publications of the Michigan State Tax Commission. 
Table 1 Empirical Results--Current Expenditures

\begin{tabular}{|c|c|c|c|c|}
\hline Variable & Parameter & Estimate & $\underline{\text { Std. error }}$ & t-stat. \\
\hline INTERCEPT & $b_{0}$ & -1.291 & 2.002 & -0.645 \\
\hline 1n POP & $b_{1}$ & 0.482 & 0.104 & 4.618 \\
\hline $\ln T$ & $b_{2}$ & -0.341 & 0.098 & -3.462 \\
\hline $\ln Z$ & $b_{3}$ & 0.757 & 0.234 & 3.241 \\
\hline In INCRATIO & $b_{4}$ & 0.145 & 0.103 & 1.401 \\
\hline In OTHERAID & $b_{5}$ & 0.190 & 0.040 & 4.750 \\
\hline DENSITY & $b_{6}$ & $-1.377 E-05$ & $2.649 \mathrm{E}-05$ & -0.520 \\
\hline PEROWN & $b_{7}$ & $-7.164 \mathrm{E}-03$ & $3.081 \mathrm{E}-03$ & -2.325 \\
\hline PERNOMW & $b_{8}$ & $2.684 \mathrm{E}-03$ & $3.378 \mathrm{E}-03$ & 0.794 \\
\hline PER65AO & $b_{9}$ & $1.891 \mathrm{E}-02$ & $9.258 \mathrm{E}-03$ & 2.042 \\
\hline
\end{tabular}

$N=115$

R-squared: $\quad 0.940$

Adjusted R-squared: 0.935

Marqinal effects, evaluated at sample medians:

Predicted by theory, $\partial E /$ RREVSHARE $=\mathrm{T} \partial \mathrm{E} / \partial \mathrm{Y}=\$ 0.0198$.

Estimated effect, $\quad$ JE/ $/$ REVSHARE $=\$ 0.5581$.

Error, $\$ 0.5383$. 


\section{Results}

Table 1 shows the results obtained when ordinary least squares is used to estimate the equation described above, using current expenditures only. The variables in logs--POP, T, Z, INCRATIO, OTHERAID--all have the signs that might be anticipated, given the model developed above. Increases in population, income, non-revenue-sharing aid, and the ratio of revenue sharing to total income all tend to increase expenditure, while increases in the tax share tend to reduce spending. The overall fit of the regression appears to be very good, as demonstrated by a R-squared of 0.940 .

The results summarized in table 1 are fairly typical of studies of local public choice. The estimates of population, income, and tax share elasticities are all within the ranges set up by Bergstrom and Goodman (1973) using separate regressions for each of several states. As is usual in the literature, the income elasticity is significantly larger than the tax share elasticity in absolute value. Although higher than average, the estimate of the effect of revenue sharing on expenditure is well within the range found by Fisher (1982); likewise, the estimates for TaE/aY are similar to the estimates summarized there. Most importantly, however, the table shows that, with respect to current expenditures, the coefficient on $b_{1}$ is significantly different from zero while the coefficient on $b_{4}$ is not. Although the descriptive statistics at the bottom of the table suggest that flypaper effects exist, these tests reject the bureaucratic model, while not rejecting the median voter model.

Table 2 presents the results when the independent variables described above are used in a regression on capital expenditures alone (outlays for construction, equipment, and land). As would be expected, the fit of the equation is not as good for capital expenditures as for current expenditures; 
Table 2 Empirical Results--Capital Expenditures

\begin{tabular}{|c|c|c|c|c|}
\hline Variable & Parameter & Estimate & $\underline{\text { Std. error }}$ & t-stat. \\
\hline INTERCEPT & $b_{0}$ & -12.325 & 8.563 & -1.439 \\
\hline In POP & $b_{1}$ & -0.704 & 0.491 & -1.434 \\
\hline $\ln T$ & $b_{2}$ & -1.354 & 0.498 & -2.719 \\
\hline $\ln Z$ & $b_{3}$ & 1.972 & 1.053 & 1.873 \\
\hline In INCRATIO & $b_{4}$ & 1.079 & 0.517 & 2.087 \\
\hline In OTHERAID & $b_{5}$ & 0.627 & 0.181 & 3.464 \\
\hline DENSITY & $b_{6}$ & $-8.350 E-05$ & $-1.117 E-04$ & -0.747 \\
\hline PEROWN & $b_{7}$ & $-8.704 \mathrm{E}-03$ & 1.309E-02 & -0.665 \\
\hline PEPNOMW & $b_{8}$ & $-9.490 E-03$ & 1.399E-02 & -0.678 \\
\hline PER65A0 & $b_{9}$ & $-5.642 \mathrm{E}-02$ & 3.963E-02 & -1.424 \\
\hline
\end{tabular}

NOTE: Ten of the cities in the sample reported no capital expenditures at a11. This presented a problem, since the dependent variable is the log of expenditures. The estimates above result when these cities are simply omitted; similar results occur when capital spending for the 10 cities is set to some small number (such as $\$ 1$ ).

$\mathrm{N}=105$

R-squared: 0.665

Adjusted R-squared: 0.633

Marginal effects, evaluated at sample medians:

predicted by theory, JE/ 2 REVSHARE $=$ TaE $/ \partial Y=\$ 0.0055$

estimated effect, $\partial E /$ DREVSHARE $=\$ 0.7479$

error, $\$ 0.7424$ 
the R-squared drops to 0.665 from its previous level of 0.94 . All of the first six parameters $\left(b_{0}\right.$ through $b_{5}$ ) are larger in absolute value than they were for the regression on current expenditures--suggesting that capital expenditures are more sensitive to the economic and financial environment of the city. Most importantly, the tests now reject the median voter model but fail to reject the Niskanen model, since $b_{4}$ is positive and significant, while $b_{1}$ turns negative but is not statistically significant.

The bottom of table 2 contains additional evidence of bureaucratic power. Under the median voter model, a $\$ 1$ increase in REVSHARE ought to be equal to T times the effect of a $\$ 1$ increase in private income. However, evaluated at

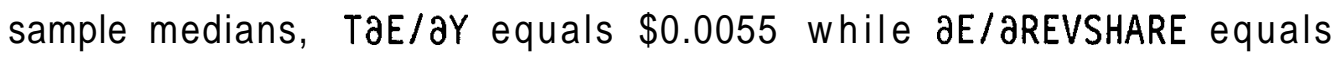
$\$ 0.7479$. The data, then, show that large flypaper effects occur in the sample. Moreover, the restriction under the budget-maximization model that DE/OREVSHARE > 1 is not violated at sample medians; adding up the marginal propensities to consume out of aid for current and capital expenditures results in JE/JREVSHARE $=\$ 1.306$.

These results suggest that a dichotomy exists with respect to the current and capital expenditure behavior of local governments. Although many explanations of this effect are possible, it seems plausible that the extra complexity of capital expenditures, along with their ability to be financed through debt, might allow the bureaucrat to get more of what he wants in this case.

A word or two of caution ought to accompany this discussion of results. Although in the joint test performed above, the bureaucratic model clearly dominates the median voter model in the case of capital expenditures, the single parameter $b_{1}$ is not significantly different from zero. This raises the possibility that another, competing model exists that might dominate the 
bureaucratic model by explaining flypaper effects without imposing the constraint that $b_{1} \leq 0$. It is, however, difficult to imagine what that model might be. It has been argued that flypaper effects occur because of fiscal illusion (mistaking the average cost of public goods for its marginal cost), differences in the tax structures of national and subnational governments, improper measurement of the variables involved, and incorrect econometric specification of the model (for a review, see Fisher [1982]). In general, however, these explanations do not fit the current data well, as they fail to explain the marked difference in observed behavior between current and capital expenditures. For example, if fiscal illusion makes the voter believe that revenue sharing lowers the per unit cost of public goods, this effect ought to be registered in both kinds of expenditures. The bureaucratic model constitutes the best available explanation of the data, although clearly more research is needed here.

In this context, it should be noted that the dichotomy observed between operating and capital expenditures has been previously noted in the literature. Nathan, Manvel, and Calkins (1975), in their study of the effects of revenue sharing on state and local governments, suggest that in the first few years of the revenue sharing program, these governments were concerned about the possibility that these funds might eventually be cut off by the federal government. For this reason, they tended to use this money for one-time capital projects rather than for extra current services that would have to be maintained in the event that revenue sharing was not renewed.

However, although the suggestion of Nathan, Manvel, and Calkins helps explain why the city council might be particularly willing to accede to the bureaucrat's demands in the area of capital expenditures, it is not a complete explanation of the patterns observed in this paper. It does not explain, for 
example, why output should be cost elastic for capital expenditures $\left(b_{1}<0\right)$ but cost inelastic for operating expenditures $\left(b_{1}>0\right)$. It does not account for the fact that the total effect of lump-sum aid is greater than the amount of the aid itself (aE/aREVSHARE > 1 for total expenditures)."

Moreover, it is not a complete explanation of the observed flypaper effects in capital expenditures. Granted, that uncertainty about grants might predispose council members toward capital expenditures over operating expenditures: this still does not explain why council fails to exercise its other option to use the aid to reduce taxes. In, short, this answer fails to explain why aid "sticks" in the public sector. The model in this paper can help complete the picture.

\section{Summary and Conclusions}

This paper has shown how a model of the type developed by Niskanen (1971) can be used in the local government context to explain flypaper effects. An empirical test of the model using the expenditures of 115 Michigan cities concluded that the model explains capital goods expenditures well, but that operating expenditures appear to be better explained by a median voter model. These are not logically inconsistent results. It is entirely possible that the monitoring devices that city councils use to restrain bureaucratic discretion (for example, using stringent budgeting and expense reporting techniques, comparing cost and output data with those of other communities, and cultivating "feedback mechanisms" from citizens and the news media to gauge the bureau's performance) work well in one context but not in another. 
A natural extension of the work in this paper would be to explore whether flypaper effects can be 'explained with other kinds of bureaucratic models. This would include, for example, theories in which the bureaucrat maximizes the size of his staff (Williamson 1965) or uses his monopoly power to fund perquisites of office, such as lavish offices, large expense accounts, short working hours, good fringe benefits, and so on (Alchian and Kessel 1962). It turns out that these models, in which the bureaucrat maximizes organizational "slack", also generate flypaper effects, for the very same reason that they occur in the Niskanen model. The bureaucrat extracts greater resources from the voter in the aid case (as compared to an increase in private income), because the voter's bargaining position is relatively weak. This alternative to bureaucratic production is not improved by the aid, but is improved by the income increase. A model of this type (and a demonstration of flypaper effects in this case) can be found in Wyckoff (1984). 
Notes

1. For a discussion of the reasonableness of these assumptions in the context of small Michigan city governments, see Wyckoff (1984).

2. In contrast to the situation at other levels of government, the local executive of small-and medium-sized cities is typically a weak participant in the political process, in the sense of possession of a separate power base. In Michigan, for example, a majority of cities use the council-manager form of government, with an appointed chief executive (see Michigan Municipal League [1972]). City managers in these cities serve entirely at the pleasure of the council, and continued success in their careers (that is, moving to better positions in bigger cities) depends upon being able to serve council member "clients" well. In the remaining cities, the mayor-council form of government, with an elected executive, is used, but because of an historical distrust of strong executives, the mayor is seldom given much power to alter the allocation of resources in city government (see Southern and Canterbury [1964]).

3. In the case of budget-maximizing bureaus, McGuire, Coiner, and Spancake (1979) have theoretically examined the utility benefit stemming from the presence of multiple bureaus. They find that substitutability of the services produced by the various bureaus is crucial in pushing the voter's utility above that associated with production by a single bureau producing all of the city's services. Since the products of local government bureaus (police and fire protection, parks and recreational services, etc.) are not very substitutable, production is treated in this paper as if it occurred under one, all-encompassing bureau.

4. Formally, the bureaucrat's problem is the solution of the following non-linear programming problem:

subject to:

$$
\max _{P_{2}, X_{2}} P_{2} X_{2}
$$

$$
\begin{aligned}
& \text { (1) } Y+T A \geq X_{1}+T P_{2} X_{2} \\
& \text { (2) } P_{2} X_{2} \geq c\left(X_{2}\right) \\
& \text { (3) } U_{0}^{v} \leq U\left(X_{1}, X_{2}\right)
\end{aligned}
$$

However, it is easy to make a case for the equalities, rather than inequalities, used above. Under normal circumstances (i.e., as long as $X$, has positive marginal utility), the utility-maximizing consumer will spend all of his income. As mentioned in the comparative statics below, the greater than unit elasticity of the median voter's demand curve insures that the budget-maximizing bureaucrat will lower prices until total revenues equal total cost. As will be revealed in the discussion of flypaper effects below, the bureaucrat's budget is inversely related to the median voter's utility, and so the assumption of budget-maximization demands that $U\left(X_{1}, X_{2}\right)$ be driven down to its minimum possible level $U_{0}^{v}$. Once these equalities are accepted, the result is the nonlinear programming problem depicted in figure 2. 
5. One possible objection to this conclusion is that increases in aid from programs such as revenue sharing are usually national in scope. Therefore, the median voter is likely to have additional aid in his new, alternative location, thus raising his $U_{0}^{v}$. Even in this case, however, flypaper effects are likely to occur because of information costs. The voter simply has more certainty about his own income levels than he does about aid levels in some alternative location. It would be costly to obtain this information, either directly, by looking at the budgets of alternative cities, or indirectly, through observation of each city's tax and service levels. For this reason, both the median voter and the council are likely to be more assertive in negotiating with departments if there is a private income increase than if conditions in some alternative city improve.

6. Rather than move, the voter may have the option of producing the good privately or doing without it entirely, although (since we have aggregated over all public services) it is much more difficult to visualize a city dismantling its entire public sector. Nevertheless, this situation also dictates that the voter do without the lump-sum aid he currently enjoys, because the city faces the prospect of losing almost all of its aid from higher levels of government if it exercises this alternative. Effort factors are built into revenue sharing programs which would severely limit the amount a non-taxing government could receive. In Michigan, a city levying no taxes would be barred from receiving any money from the state's income, intangibles, and single business taxes; similarly, the federal general revenue sharing program excludes non-taxing jurisdictions from receiving much aid by use of a formula incorporating tax effort factors, and by a provision that limits revenue sharing entitlements to a fixed percent of the money raised by the city from other sources.

7. To avoid confusion here, the reader should note that Romer and Rosenthal's reversion level is an actual level of public spending, while the reversion in the current model refers to a utility level. For this reason, the specifics of the two models are entirely different. Under the Romer and Rosenthal model, for example, an increase in aid increases the reversion level of spending; in the current model, an increase in aid does not affect the reversion level of utility.

8. Recently, two papers have appeared which challenge this assumption in a new and fundamental way: Brown and Saks (1983) and Beck (1984). Whereas Bergstrom and Goodman assume monotonic individual demands and deal with the problem of nonmonotonic aggregate demands, these papers try to show that individual demands are nonmonotonic. The empirical work in these papers tries to establish this nonmonotonicity by including the square of median income, and the Gini index for the distribution of family income, in a cross-section regression on local expenditures. The significance of these variables was tested in the present study by including the Gini coefficient, the square of median total income $\left(Z^{2}\right)$, the Gini coefficient times median total income, and the Gini coefficient times the square of median total income, in the regressions described below. The Gini index was calculated according to the procedures used in Beck (1984, p. 60). None of these variables were significant at even the 10 percent level, and an F-test of their combined significance failed to reject the hypothesis that they all had zero coefficients at the 10 percent level. 
9. Regardless of the actual incidence of these business taxes, it seems unlikely that the median voter will be able, in most instances, to isolate the complex effects upon his budget of the indirect "taxes" (increases in local prices, etc.) caused by business taxation. For this reason, business taxes were omitted from the model.

10. The sample has been deliberately restricted to these cities for several reasons. Cities with populations below 2,500 could not be used because of a lack of data on median family income. Cities with populations greater than 57,000 were not used because of the possibly different nature of monitoring and budgeting procedures in those cities. The cutoff point of 57,000 was used because, with respect to 1970 population, there exists a natural break in the Michigan city data that falls between the city of Wyoming (population 56,560) and the next largest city, Kalamazoo (population 85,555). The suburbs of Detroit have been eliminated, because Goldstein and Pauly (1981) have shown that studies based upon the median voter-median income correspondence (assumption A.7) will be biased by the Tiebout process when applied to metropolitan areas.

11. These difficulties remain even if the arguments of Nathan, et al., are supplemented with one of the alternative flypaper theories mentioned above. For example, in the fiscal illusion model, it is difficult to show how DE/OREVSHARE could exceed one. Since $\partial E / \partial Y$ is about $\$ 0.02$ for total expenditures, this leaves about $\$ 0.98$ to be explained by the effect of aid on the average (and perceived marginal) price of public goods. But a $\$ 1$ increase in aid, evaluated at sample medians, has only a tiny effect on average price--a reduction of less than 0.0001 percent. 


\section{References}

Alchian, Armen A., and Reuben A. Kesse1. "Competition, Monopoly, and the Pursuit of Money," in Aspects of Labor Economics. A report of the National Bureau of Economic Research, Princeton, NJ: Princeton University Press, 1962, pp. 157-75.

Beck, John H. "Nonmonotonic Demand for Municipal Services: Variation Among Communities," National Tax Jounal, vol. 37, no. 1 (March 1984), pp. 55-67.

Bergstrom, Theodore C., and Robert P. Goodman. "Private Demands for Public Goods," American Economic Review, vol. 63, no. 3 (June 1973), pp. 280-96.

Black, Duncan. "On the Rationale of Group Decision Making," Journal of Political Economy, in Kenneth J. Arrow and Tibor Skitovsky, eds., Readings in Welfare Economics, Homewood, ILL: Richard D. Irwin, 1969, pp. 133-46.

Borcherding, Thomas E., and Robert T. Deacon. "The Demand for the Services of Non-Federal Governments," American Economic Review, vol. 62, no. 5 (December 1972), pp. 891-901.

Bowen, Howard R. "The Interpretation of Voting in the Allocation of Economic Resources," in Kenneth J. Arrow and Tibor Skitovsky, eds., Readings in Welfare Economics, Homewood, ILL: Richard D. Irwin, Inc., 1969, pp. 115-32.

Bradford, David F., and Wallace E. Oates. "The Analysis of Revenue Sharing in a New Approach to Collective Fiscal Decisions," Quarterly Journal of Economics, vol. 85, no. 3 (August 1971), pp. 416-39.

Brown, Byron W., and Daniel H. Saks. "Spending for Local Public Education: Income Distribution and the Aggregation of Private Demands, "Public Finance Quarterly, vol. 11, no. 1 (January 1983), pp. 21-45.

Filimon, Radu, Thomas Romer, and Howard Rosenthal. "Asymmetric Information and Agenda Control: The Bases of Monopoly Power in Public Spending," Journal of Public Economics, vol: 17, no. 1 (February 1982), pp. 51-70.

Fisher, Ronald C. "Income and Grant Effects on Local Expenditure: The Flypaper Effect and Other Difficulties," Journal of Urban Economics, vol. 12, no. 3 (November 1982), pp. 324-45.

Goldstein, G.S., and M.V. Pauly. "Tiebout Bias on the Demand for Local Public Goods," Journal of Urban Economics, vol. 16, no. 2 (October 1981), pp. $131-\overline{43}$. 
Gramlich, Edward M. "Intergovermental Grants: A Review of the Empirical Literature," in Wallace E. Oates, ed., The Political Economy of Fiscal Federalism. Lexington, MA: Lexington Press, 1977, pp. 219-39.

Hotelling, Harold. "Stability in Competition," Economic Journal, vol. 39 (March 1929), pp. 41-7.

Inman, Robert P. "Testing Political Economy's 'As If Proposition: Is the Median Voter Really Decisive?" Public Choice, vol. 33, no. 4 (1978), pp. 45-65.

McGuire, Thomas, Michael Coiner, and Larry Spancake. "Budget-Maximizing Agencies and Efficiency in Government," Public Choice, vol. 34 (1979), pp. 333-57.

Michigan Municipal League. "Organization of City and Village Governments in Michigan," Michigan Municipal League Technical Topics. No. 32 , revised. (May 1972).

Nathan, Richard P., Allen D. Manvel, and Susannah E. Calkins. Monitoring Revenue Sharing. Washington, DC: Brookings Institution, 1975.

Niskanen, William A. Bureaucracy and Representative Government. Chicago: Aldine-Atherton, Inc., 1971.

Patinkin, Don. "Demand Curves and Consumer's Surplus," in Carl F. Christ et al., eds., Measurement in Economics: Studies in Mathematical Economics and Econometrics in Honor of Yehuda Grunfeld, Stanford: Stanford University Press, 1963, pp. 83-112.

Romer, Thomas, and Howard Rosenthal. "An Institutional Theory of the Effect of Intergovernmental Grants," National Tax Journal, vol. 33, no. 4 (December 1980), pp. 451-58.

Southern, Dodd A., and Charles T. Canterbury. Michigan Mayor-Council Charters. Ann Arbor, MI: University of Michigan Institute of Public Administration, 1964.

Williamson, Oliver E. The Economics of Discretionary Behavior: Managerial Objectives in a Theory of the Firm. Englewood Cliffs, NJ: Prentice Hall, Inc., 1965.

Wyckoff, Paul G. "Bureaucracy, Efficiency, and Local Public Choice: An Empirical Test of Some New Implications of Bureaucratic Public Service Provision," unpublished Ph.D. dissertation, University of Michigan, 1984. 